\title{
Pelvic Ring Avulsion Fractures in Young Footballers: Three Cases Report
}

\author{
Genç Futbolcularda Pelvik Halkanın Avulsiyon Kırrğı: Üç Olgu Sunumu
}

\author{
Ahmet Imerci', Yavuz Akalın², Muhammet Bozoğlan³, Umut Canbek4, Levent Sürer', Ömer Metin ${ }^{6}$ \\ 'Department of Orthopaedics and Traumatology, Erzurum Palandöken State Hospital, Erzurum, Turkey \\ 2Department of Orthopaedics and Traumatology, Bursa Çekirge Education and Research Hospital, Bursa, Turkey \\ ${ }^{3}$ Department of Orthopaedics and Traumatology, Mardin Derik State Hospital, Mardin, Turkey \\ ${ }^{4}$ Department of Orthopaedics and Traumatology, Muğla Sıtkı Koçman University, School of Medicine, Muğla, Turkey \\ ${ }^{5}$ Department of Orthopaedics and Traumatology, Bodrum Acıbadem Hospital, Muğla, Turkey \\ ${ }^{6}$ Department of Orthopaedics and Traumatology, Erzurum Regional Education and Research Hospital, Erzurum, Turkey
}

\section{ABSTRACT}

Introduction: The frequency and importance of sports injuries is increasing day by day and $2 \%$ to $5 \%$ of all sports injuries are in the inguinal region. These injuries cause dilemmas in terms of diagnosis and treatment even for experienced doctors. In order to the problem to be correctly dealt with, a thorough anamnesis and physical examination should be carried out at the first.

Case Report: In this article, we present the stories of three amateur footballers aged 24, 19 and 16 who came to our clinic with the problem of which they had sudden inguinal pains in shooting position and later had difficulty walking due to this pain. In the anterior-posterior pelvic graphs and computerized tomography, three of the patients were diagnosed with spina iliaca anterior inferior (SIAI) avulsion fracture.

Conclusion: In the acute period, patients were given conservative treatment including non-steroid anti-inflammatory drugs (NSAID) and bed rest. Following a one-week bed rest, mobilization with crutches was initiated. At the end of the sixth week, crutches were abandoned and at the end of the eighth week, sportive activity was allowed.

Keywords: Gain pain, avulsion fracture, football, radiography Received: 24.11.2012 Accepted: 11.03.2013

\section{ÖZET}

Giriş: Spor yaralanmalarının sıklığı ve önemi günden güne artmaktadır ve bütün spor yaralanmalarının yüzde 2 ile $5^{\prime} i$ kasık bölgesinde oluşur. Bu yaralanmalar deneyimli ellerde bile tanı ve tedavi açısından ikilem teşkil eder. Sorunun doğru olarak değerlendirilmesi için öncelikle çok dikkatli bir anamnez ve fizik muayene ile başlamalıdır.

Olgu Sunumu: Bu yazıda, şut pozisyonu esnasında ortaya çıkan ani başlayan kasık ağrısı ve ağrıya bağlı yürümede zorluk şikayeti ile polikliniğimize başvuran 24, 19 ve 16 yaşlarında üç amatör futbolcuda tespit edilen avulsiyon kırığı anlatılmaktadır. Çekilen ön-arka pelvis grafisi ve bilgisayarlı tomografide üç hastada spina iliaka anterior inferior (SIAI) avulsiyon kırığı saptandı.

Sonuç: Hastalara, akut dönemde non-steroid antienflamatuvar ilaç ve yatak istirahatinden oluşan konservatif tedavi uygulandı. 1 haftalık yatak istirahati sonrası koltuk değnekleri ile mobilizasyona başlandı. 6.haftanın sonunda koltuk değneklerinin kullanımı sonlandırılı ve 8. haftanın sonunda sportif aktiviteye başlanmasına izin verildi.

Anahtar Kelimeler: Kasık ağrısı, avulsiyon kırığı, futbol, radyografi Geliş Tarihi: 24.11.2012 Kabul Tarihi: 11.03.2013

\section{Introduction}

Pelvic ring avulsion injuries are often seen in sportsmen during puberty but are also recorded with a lower ratio in adults. Avulsion fractures in sportsmen usually occur due to excessive tensile force in muscular joints of the epiphyseal plate (1-3). The fractures in this part are among the main reasons for inguinal pain in sportsmen and, in rare situations, can deteriorate and disappoint both the doctor and the patient (1).

These injuries are frequently seen in sports that consist of sharp turning moves, kicking and running and particularly in footballers $(2,4)$. These acute injuries are often due to an overextension of a muscle and can frequently be associated with sudden 
direction changes while running (2). Diagnosis of inguinal pain in sportsmen is difficult.

The reason for this is that the anatomy of the region is complicated and usually two or more injuries occur together. Problems such as intra-abdominal pathology, genitourinary anomalies, referred lumbosacral pain and hip joint disorders (arthritis, synovitis, avascular necrosis etc.) are disorders which should be eliminated at the outset (5).

In this article, three spina iliaca anterior inferior (SIAI) avulsion fractures, which occurred while shooting in three young male footballers aged 24, 19 and 16, are presented.

\section{Case Reports}

\section{Case 1}

A twenty four-year-old amateur male footballer came to our clinic with right inguinal pain which started when he was shooting 3 days previouslyln the physical examination, there was no visible injury or swelling. The patient felt pain during the palpation of the front right iliac crest. Measured with the goniometer, joint movement of the right hip was found to be full in all directions. The patient had pain during hip flexion and extension. In the measurements carried out through manual muscle strength testing, the patient's right hip flexors were found to be $4 / 5$ and right hip and knee extensors were $5 / 5$. In the radiological examination, it was observed that there was no problem in the right front iliac crest in the anterior-posterior pelvic graph but there was a separation compared to the rightside. This finding was consistent with SIAI avulsion fracture diagnosis (Figure 1).

\section{Case 2}

A nineteen-year-old patient was examined with the problem of difficulty in walking upon a sudden sharp pain which occurred in his right hip while shooting in a football match on the previous day. The region concerning SIAI on the right hip was sensitive to palpation. The patient could not flex his hips while his knees were extended. The neurovascular examination was normal. In the radiological examination and computerized tomography (CT), a semilunar avulsion fracture was observed in the right SIAI (Figure 2a, b).

\section{Case 3}

A sixteen-year-old amateur football player came to our clinic because of a pain in the left inguinal region, which occurred after shooting in a football match. In the physical examination, painful hip flexion was observed. A radiograph showed an avulsion fracture of the SIAI (Figure 3).

All patients were given the same treatment protocol and it was initiated as treatment through non-steroid anti-inflammatory drugs (NSAID) and bed rest. Upon the weakening of the acute pain, at the end of the first week they were allowed mobilization with crutches.

In the first examination of the patients at the end of the second week, they were observed to be able to walk without crutches and with min-

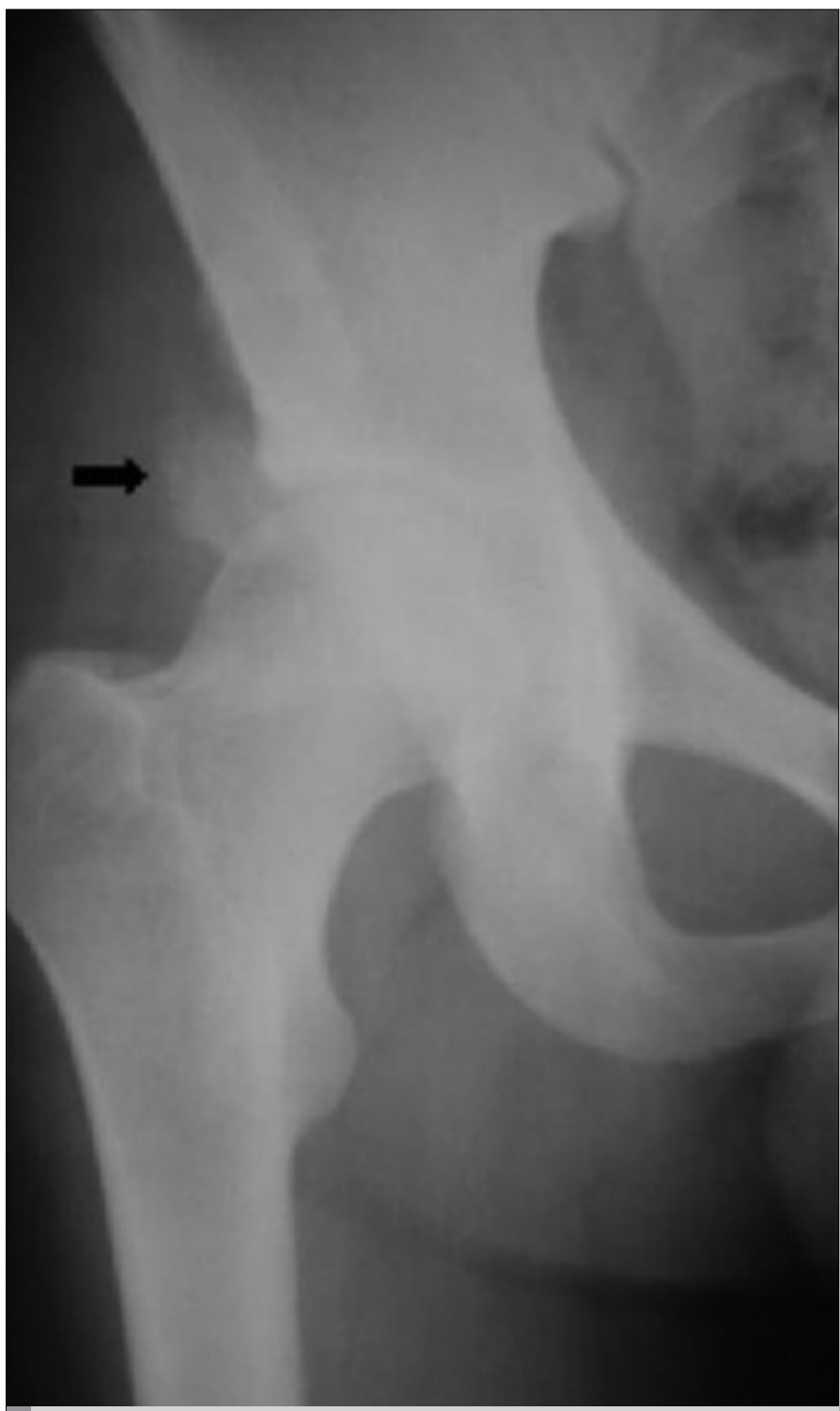

Figure 1. Right hip antero-posterior radiography revealed avulsion and downward separation of the right anterior inferior iliac spine due to pulling of the rectus femoris muscle (Black arrow)

imal pain. At the end of the fourth week, crutches were abandoned and at the end of the eighth week, the patients were allowed to start light sports activities. In the examination at the end of the fourth month, the patients' left hip movements were measured to be full by goniometer, SIAI were painless in palpation and muscle strength of the hip muscles was measured as 5/5 through manual muscle testing. All patients returnedto football without any problems. Informed consent were obtained from the patients' families and patients.

\section{Discussion}

The most frequently injured body parts of footballers are knees, tarsal ligaments and quadriceps muscles. In one season, the ratio of acute inguinal injuries in footballers is 5\%-15\% (6). Acute inguinal injuries are diagnosed by doctors through physical examination or 

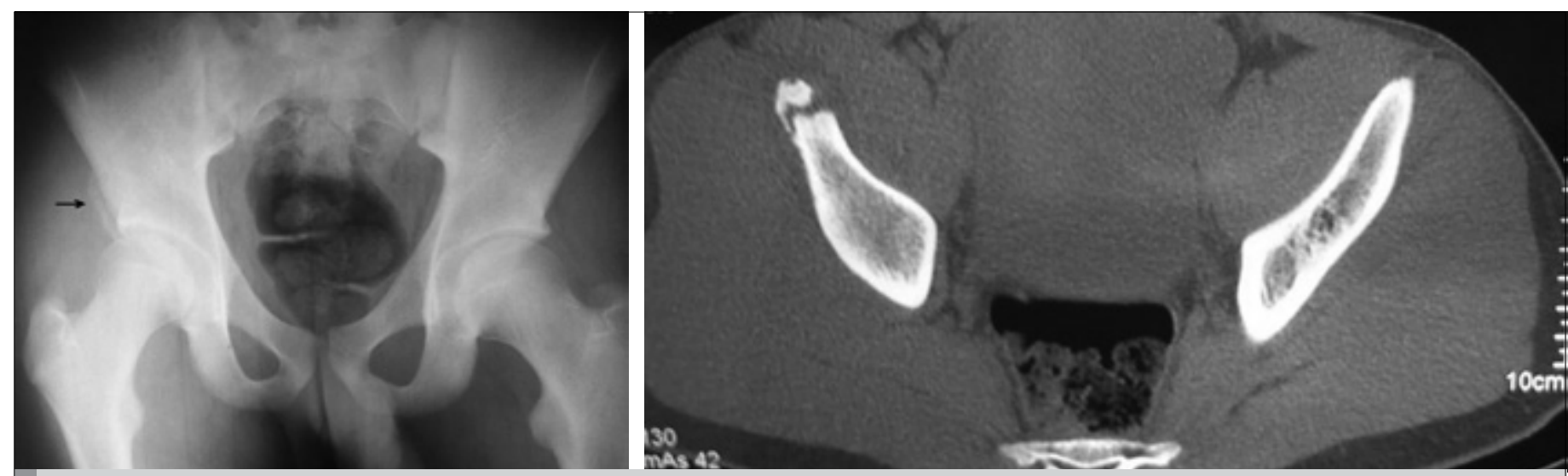

Figure 2. Right anterior inferior iliac spine fracture, a. Antero-posterior radiograph of the pelvis (arrow). b. Computed tomography image

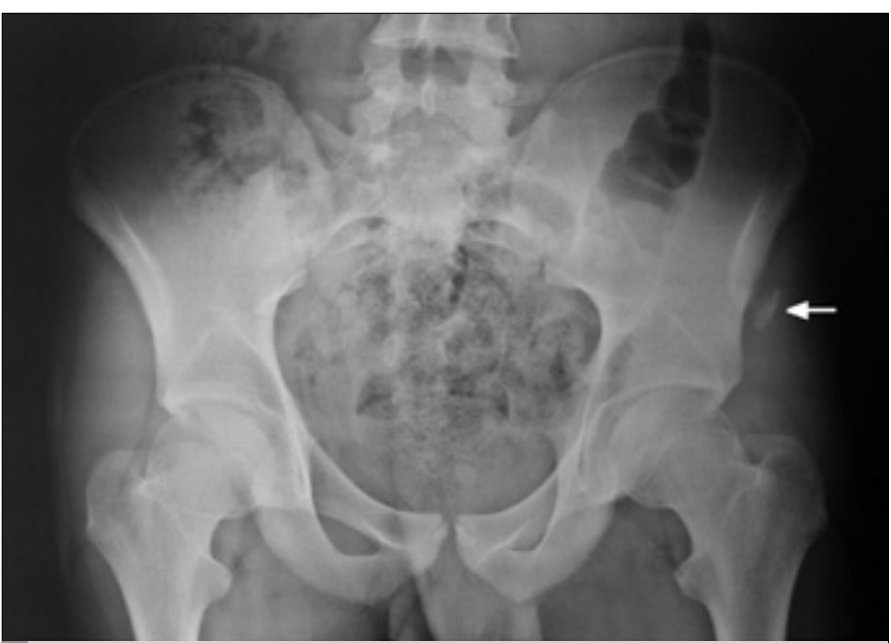

Figure 3. Anteroposterior radiograph of the pelvis. A piece of bone (arrow) was avulsed from the left anterior inferior iliac spine (arrow)

imaging methods $(1,2,7,8)$. The most common reason for inguinal pain in footballers is adductor muscle stress (5).

Pelvic avulsions usually occur in adolescents and are observed in three regions. The first one is avulsions from the spina iliaca anterior superior (SIAS), occurring especially due to sudden sartorius contractions during jumps. The second one is from SIAI and occurs due to strong rectus femoris contractions in footballers especially while kicking. The third one is seen in the ischial tuberosity and occurs during sprinting and due to the strong contraction of hamstring muscles in challenging sports (5).

Although in one way avulsion fractures I are rare injuries in adolescents, they frequently occur during sports activities $(3,5)$. SIAI avulsion is 14.8\% to $22.1 \%$ less frequent than other pelvic avulsion injuries $(4,7,8)$.

Anterior-posterior radiographies are usually sufficient for the diagnosis of SIAI. CT and Magnetic Resonance Imaging can be used in order to determine exactly how much separation has occurred in the fracture fragment $(2,6-8)$. If the avulsion fracture is less than $2 \mathrm{~cm}$, it is treated with relative bed rest, ice, NSAID and by freeing of load until the pain is relieved.

If the fracture is more than $2 \mathrm{~cm}$, surgically open reduction and internal fixation are needed $(6,7)$. These injuries can easily be ignored or misdiagnosed $(5,8)$. A delay in diagnosis leads to the pain continuing and the sportsman to lose performance $(2,5)$. Our patients were given conservative treatment and went back to sports activities in the fourth month after the injury without any complications.

\section{Conclusion}

It is important in diagnosis to suspect these injuries. Doctors should have a full knowledge of the complex structure of the hip region and consider possible different diagnoses. A systematic physical examination is of great importance. For pains occurring in footballers due to shooting in the anamnesis, possible pelvic ring avulsion fractures should be considered and imaging methods should be used. Also, in sportsmen who have not yet reached skeletal maturity, pelvic ring avulsion fractures should be considered for the differential diagnosis of sudden inguinal pains.

Conflict of Interest: No conflict of interest was declared by the authors.

Peer-review: Externally peer-reviewed.

Author Contributions: Concept - A.I., Y.A.; Design - Y.A.,L.S.; Supervision - A.I., L.S.; Funding - M.B., U.C.; Materials - U.C., M.B.; Data Collection and/or Processing - Ö.M., Y.A.; Analysis and/or Interpretation - A.I., Ö.M.; Literature Review - Y.Z., L.S.; Writer - M.B., L.S.; Critical Review - L.S., U.C.

Çıkar Çatışması: Yazarlar herhangi bir çıkar çatışması bildirmemişlerdir.

Hakem değerlendirmesi: Dış bağımsız.

Yazar Katkıları: Fikir - A.I., Y.A.; Tasarım - Y.A., L.S .; Denetleme - A.I., L.S.; Kaynaklar - M.B., U.C.; Malzemeler - U.C., M.B.; Veri toplanması ve/veya 
işlemesi - Ö.M., Y.A.; Analiz ve/veya yorum - A.I.., Ö.M.; Literatür taraması Y.Z., L.S.; Yazıyı yazan - M.B.,L.S.; Eleştirel İnceleme - L.S., U.C.

\section{References}

1. LeBlanc KE, LeBlanc KA. Groin pain in athletes. Hernia 2003; 7: 68-71. [CrossRef]

2. Bulbul M, Ayanoglu S, Imren $Y$, Gurbuz H. Adolescent in conservative treatment of avulsion fracture of inferior anterior iliac spine (Two cases report). ADÜTip Fakültesi Dergisi 2011; 12: 49-51.

3. Morelli V, Smith V. Groin injuries in athletes. Am Fam Physician 2001; 64: 1405-14.

4. Paajanen H, Ristolainen L, Turunen H, Kujala UM. Prevalence and etiological factors of sport-related groin injuries in top-level soccer com- pared to non-contact sports. Arch Orthop Trauma Surg 2011; 131: 261-6. [CrossRef]

5. Söyüncü Y, Gür S. Avulsion injuries of the pelvis in adolescents. Acta Orthop Traumatol Turc 2004; 38: 88-92.

6. Atalar H, Kayaoğlu E, Yavuz OY, Selek H, Uraş I. Avulsion fracture of the anterior inferior iliac spine. Ulus Travma Acil Cerrahi Derg 2007; 13: 322-5.

7. Rajasekhar C, Kumar KS, Bhamra MS. Avulsion fractures of the anterior inferior iliac spine: the case for surgical intervention. Int Orthop 2001; 24: 364-5. [CrossRef]

8. Yildiz C, Yildiz Y, Ozdemir MT, Green D, Aydin T. Sequential avulsion of the anterior inferior iliac spine in an adolescent long jumper. Br J Sports Med 2005; 39: e31. [CrossRef] 